\title{
Macrophage migration inhibitory factor (MIF) in the development and progression of pulmonary arterial hypertension
}

${ }^{1}$ Neonatal-Perinatal Medicine, Pediatrics Department Cohen Children's Hospital at New York, Northwell Health System

${ }^{2}$ The Center for Heart and Lung Research, The Feinstein Institute for Medical Research, Manhasset, New York, USA

${ }^{3}$ School of Medicine, Hofstra University, Hempstead, New York, USA

4 The Elmezzi Graduate School of Molecular Medicine, Manhasset, New York, USA

`Email:mahmed2@northwell.edu http://dx.doi.org/

10.21542/gcsp.2018.14

Received: 11 January 2018

Accepted: 18 April 2018 (C) 2018 The Author(s), licensee Magdi Yacoub Institute. This is an open access article distributed under the terms of the Creative Commons Attribution license CC BY-4.0, which permits unrestricted use, distribution and reproduction in any medium, provided the original work is properly cited.
Mohamed Ahmed ${ }^{\mathbf{1}, \mathbf{2}, 3 *}$, Edmund Miller $\mathbf{2 , 3 , 4}$

\section{ABSTRACT}

Macrophage migration inhibitory factor (MIF) has been described as a pro-inflammatory cytokine and regulator of neuro-endocrine function. It plays an important upstream role in the inflammatory cascade by promoting the release of other inflammatory cytokines such as TNF-alpha and IL-6, ultimately triggering a chronic inflammatory immune response. As lungs can synthesize and release MIF, many studies have investigated the potential role of MIF as a biomarker in assessment of patients with pulmonary arterial hypertension (PAH) and using anti-MIFs as a new therapeutic modality for PAH.
Cite this article as: Ahmed M, Miller E. Macrophage migration inhibitory factor (MIF) in the 


\section{PULMONARY ARTERIAL HYPERTENSION (PAH)}

PAH is a devastating disease that leads to progressive systemic hypoxemia, right ventricular failure and death ${ }^{1}$. PAH demonstrates rapid deterioration after diagnosis, with an average survival time for primary pulmonary hypertension of only 2.8 years, and an estimated 5 year survival rate of between $21-34^{2,3}$. Although previously considered a rare disease, over the last two decades, there has been an increase in the diagnosis possibly due to the increased awareness of the physician and improved diagnosis methods ${ }^{4}$. PAH can occur in association with chronic lung disorders, with hypoxia playing a pivotal role in the etiology. Hypoxia induces pulmonary vessel constriction and persistent hypoxia results in pulmonary vascular remodeling resulting in increased vessel wall thickness and narrowing of the vessel5,6 (Figure 1). Pulmonary vascular remodeling chronically increases pulmonary vascular resistance (PVR), leading to right ventricular failure, decreased left ventricular preload and reduced cardiac output. The remodeling also causes mismatch of blood flow and ventilation $(\mathrm{V} / \mathrm{Q})$, which, together with decreased cardiac output and possible cardiac shunt, lead to further hypoxia. A major factor in the rapid progression of $\mathrm{PAH}$ symptoms may be due in part to the creation of a vicious cycle: PAH can be initiated by hypoxia, itself causes hypoxia, and hypoxia in return exacerbates $\mathrm{PAH}$.

Current therapies for PAH are relatively ineffective and their benefits limited to improving ability to exercise. They include prostacyclin and its analogues, endothelin receptor antagonists, and phosphodiesterase type 5 inhibitors $^{7-9}$. Notably, current therapies do not significantly improve mortality, rate of clinical progression of disease, or WHO functional class ${ }^{10,11}$. The limitation of current treatment suggests the need for a better understanding of the pathogenesis and identification of new therapeutic targets for this lethal disease.

\section{Role of Hypoxia in Pulmonary Hypertension}

A
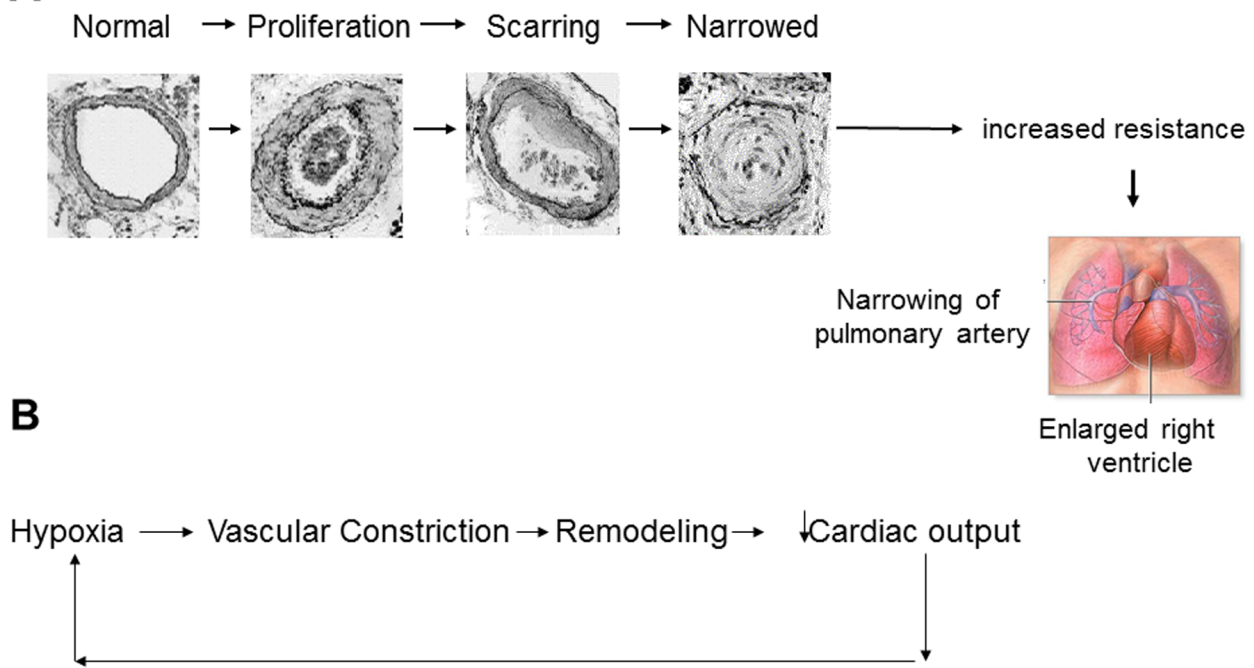

Figure 1. Role of hypoxia in pulmonary hypertension. (A) Hypoxia induces pulmonary vascular remodeling resulting in increased vessel wall thickness and narrowing of the vessel. The remodeling chronically increases pulmonary vascular resistance. (B) A major factor in the rapid progression of PAH pathology is due in part to the creation of a vicious cycle: Hypoxia induces vasoconstriction, which itself adds to the hypoxia, and hypoxia in return exacerbates PAH. 


\section{VASCULAR REMODELING}

Vascular remodeling leads to increased vessel wall thickness and narrowing of the vessel lumen ${ }^{5,6}$. Endothelial, fibroblasts and smooth muscle (SMC) are the principal intimal, adventitial and medial cells of the vascular wall, respectively. Chronic hypoxia induces pulmonary vascular cell proliferation and remodeling, but the mechanisms involved remain unclear. While morphological changes to the intima are observed, they are usually minimal ${ }^{12}$. Chronic hypoxia induces structural changes to the pulmonary arteries including the appearance of SMC-like myofibroblasts expressing $\alpha$-smooth muscle actin, in previously non-muscularized vessels. While hypoxia-induced remodeling is associated with medial hypertrophy, direct stimulation of SMC proliferation by hypoxia remains controversial ${ }^{13}$.

There are reports of hypoxia-driven smooth muscle cell proliferation ${ }^{14,15}$, but several in vitro studies have shown that hypoxia does not directly increase SMC proliferation ${ }^{16-18}$ or may actually decrease proliferation ${ }^{19,20}$. However, fibroblasts which are less differentiated than the other two cell types, have a greater proliferative response to hypoxia than either endothelial cells or SMC ${ }^{20-23}$. Fibroblasts are uniquely positioned in the scheme of remodeling being able to rapidly proliferate, contract, migrate, synthesize cytokines and other mediators, and transdifferentiate into other cell types such as the SMC-like myofibroblast ${ }^{24}$. Animal models indicate that the adventitia undergoes the earliest and most profound changes under hypoxic conditions 25,26 and in vitro, hypoxia induces fibroblast proliferation in the absence of any exogenous co-mitogen ${ }^{27}$.

\section{MACROPHAGE MIGRATION INHIBITORY FACTOR (MIF)}

MIF was originally described over 50 years ago in studies of delayed hypersensitivity in which it was suggested that lymphoid cells released soluble materials that inhibited the random migration of peritoneal exudate cells in vitro ${ }^{28,29}$. This resulted in the original nomenclature, but since that time, a multiplicity of functions have been assigned to the molecule has led to the less formal epithet of simply MIF30.

MIF is a conserved protein of $12.5 \mathrm{kDa}$, of which homologues can be found in plants, nematodes and vertebrates. In its active form, it is a homotrimer which is associated with two distinct enzymatic activities. The first, a phenylpyruvate tautomerase ${ }^{31}$, residing within the hydrophobic pocket between adjacent monomers. This tautomerase activity and structural relationship are similar to a second human protein, D-dopachrome tautomerase (D-DT) ${ }^{32}$, with which human MIF shares around 34\% sequence homology. The similarities between structures and activities of the two molecules have led to the D-DT designation as 'MIF-2'33.

While the relevance of the tautomerase activity to human disease remains unclear, the hydrophobic pocket within which the activity is located binds to cell surface CD74 molecules 34 thereby activating its CD44 co-receptor initiating cellular activation, cell proliferation and inhibition of apoptosis ${ }^{35,36}$. The second MIF catalytic activity is a thiol-protein oxidoreductase ${ }^{37}$ within a conserved [Cys ${ }^{57}$-Ala-Leu-Cys ${ }^{60}$ ] region of the molecule. This antioxidant activity has been shown to be particularly relevant to situations of cellular oxidative stress ${ }^{38-41}$. Thus, these two characteristics of MIF alone make it a molecule of interest in the development and progression of pulmonary arterial hypertension.

Furthermore, MIF is a potent proinflammatory cytokine involved in both chronic and late-stage acute inflammation and plays a key role in inflammatory cell proliferation. It is stored within cytoplasmic pools and can be released to extracellular compartments 
following interaction with the Golgi complex-associated protein p115 $5^{42}$. Extracellular release of MIF is initiated by a series of factors including cytokines, materials from Gram-positive or Gram-negative bacteria 43,44 oxidative stress ${ }^{45}$, and steroids ${ }^{30}$. MIF is involved in wound healing ${ }^{46}$, synoviocyte proliferation ${ }^{47}$, and transformation from chronic inflammation to tumorigenesis ${ }^{48,49}$.

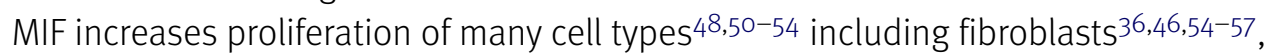
endothelial cells ${ }^{58}$, and SMCs 59,60 . MIF also appears to be involved in systemic vascular remodeling, including carotid intima-media thickening ${ }^{60,61}$, and restenosis after vascular injury ${ }^{60}$. One possible mechanism of MIF's proliferative effects is through the inhibition of p53, an endogenous cell cycling inhibitor that induces $\mathrm{G}_{1}$ stage arrest or apoptosis ${ }^{62,63}$, and is also involved in pulmonary arterial smooth muscle cell proliferation ${ }^{50}$.

\section{MIF AND THE LUNG}

While early studies showed the anterior pituitary as a possible source of circulating $\mathrm{MIF}^{64}$, more recent studies have shown that in severe acute inflammation, the lungs are a major source of the circulating MIF, which can have a profound effect on cardiovascular function ${ }^{65,66}$. While MIF is a normal component in the epithelial lining fluid of the lung there is a significant increase in accumulation in the alveolar airspaces in the acute respiratory distress syndrome (ARDS) ${ }^{67}$. The increased lung MIF is both at the gene expression and protein levels and can be associated with haplotypes located in the $3^{\prime}$ end of the MIF gene ${ }^{68}$. Furthermore, the increased MIF concentrations due to a particular challenge, in both the alveolar spaces and the plasma, are age-dependent ${ }^{69}$. Thus, while increased extracellular MIF emanating from the adult lung appear to be detrimental, a recent study by Roger et al showed that in very preterm infants, low levels of MIF on postnatal day 6 were associated with an increased risk of developing bronchopulmonary dysplasia and late-onset neonatal sepsis ${ }^{70}$.

There are also several chronic inflammatory lung-associated pathologies that have been noted to be associated with changes in MIF. In particular, in idiopathic pulmonary fibrosis there is increased MIF expression in areas of remodeling, bronchiolar and alveolar epithelium, and ongoing fibrosis ${ }^{71,72}$. In systemic sclerosis, where MIF may be involved in the amplifying proinflammatory loop leading to scleroderma tissue remodeling ${ }^{73}$, an MIF promoter polymorphism is associated with susceptibility to pulmonary arterial hypertension in diffuse cutaneous systemic sclerosis (SSc) ${ }^{74}$. Functional promoter polymorphisms in the MIF gene, such as the high-expression MIF haplotype, $\mathrm{C} 7$, which is defined by $-173^{*} \mathrm{C}$ and -794 with 7 CATT repeats, can also affect the clinical presentation of $\mathrm{SSc}^{75}$.

In addition, recent studies in a cohort of individuals with chronic obstructive pulmonary disease (COPD), demonstrate an association with increased plasma MIF and its acute exacerbations ${ }^{76}$, although others have suggested that MIF and its receptor are required for the preservation of normal alveolar structure and normal pulmonary endothelial cell apoptosis 77,78 .

\section{RELATIONSHIP BETWEEN HYPOXIA AND MIF}

Several studies describe a clear link between MIF and the presence of hypoxia. Hypoxia can lead to the secretion and elevation of MIF in fibroblasts 79 , cardiac myocyte ${ }^{80}$, monocytes ${ }^{81}$, and endothelia ${ }^{81}$. Hypoxia induces the stabilization of the transcription factor hypoxia inducible factor-1 alpha (HIF-1 $\alpha$ ). When stabilized, HIF-1 $\alpha$ binds with aryl hydrocarbon receptor nuclear translocator (ARNT)/HIF-1 $\beta$. This hetero-dimer binds 
to elements found in the promoters of many hypoxia-responsive genes, leading to the expression of these target proteins such as vascular endothelial growth factor (VEGF), endothelin-1 (ET-1), and erythropoietin (EPO) ${ }^{82}$.

In 2006, Welford et al. demonstrated that the MIF gene contains an hypoxia response element within its promoter, which could explain the hypoxia induced MIF elevation 79. This mechanism also has been suggested by others ${ }^{83-86}$. Furthermore, hypoxia in the presence of increased TNF $\alpha$ leads to an increase of the MIF receptor molecule CD44 on the surface of monocytes ${ }^{87}$.

Once released, MIF can contribute to hypoxic pulmonary vasoconstriction, which if maintained can lead to pulmonary vascular remodeling ${ }^{88}$. Zhang et al have shown that MIF affects delayed hypoxia-induced pulmonary hypertension and suggest that the action is via agonist enhancement on smooth muscle cells. However, while much is discussed about the apparently detrimental aspects of MIF inflammatory activity, it must be remembered that MIF has been shown to be protective in the early stages of ischemia.

Under ischemic conditions the extracellular release of MIF and its interaction with the $C D 74$ receptor activates AMPK, thereby promoting glucose uptake and protects the cardiomyocyte ${ }^{39}$. In addition, the anti-oxidant activities of MIF can reduce intracellular oxidative stress and reduce injury in the post-ischemic heart ${ }^{38}$.

\section{RELATIONSHIP BETWEEN HYPOXIA, MIF, AND PULMONARY VASCULAR CELL PROLIFERATION}

Pulmonary vascular cell proliferation is the major pathological change during hypoxiainduced remodeling. The pulmonary vascular wall is composed of three layers of different cells: endothelial cells in the intima, SMCs in the media, and fibroblasts in the adventitia. Hypoxia in vivo induces proliferation of all of these cells, but only fibroblast proliferation is induced by hypoxia in vitro ${ }^{13}$ in the absence of exogenous co-mitogens. In addition, fibroblast proliferation takes place earlier after hypoxic exposure than $\mathrm{SMCs}^{13}$, and hypoxia induces SMC proliferation only in co-culture with fibroblasts ${ }^{20}$.

Therefore, it appears that fibroblasts are essential to trigger the vascular remodeling process, perhaps because they are less differentiated and prepared for local injury repair $^{27}$. Fibroblasts are remarkably plastic, allowing for rapid migration, proliferation, cytokine expression, and differentiation ${ }^{27}$. Fibroblasts differentiation to myofibroblasts ${ }^{24}$ is a critical step for vascular remodeling and hypoxia alone can induce fibroblast proliferation ${ }^{20,27,89}$ and differentiation to myofibroblasts ${ }^{90,91}$. Studies indicate that the lung is a major source of MIF $^{2}$, is released from the lungs in patients with $\mathrm{PAH}^{93}$ and plays a key role in hypoxia-induced cell proliferation 45 .

\section{MIF AND PULMONARY ARTERIAL HYPERTENSION}

PAH is a critical, and potentially devastating, clinical syndrome. The disorder, is particularly affects the small pulmonary arteries, and is characterized by vascular narrowing due to high-tone and abnormal vaso-reactivity. These abnormalities, if not corrected, lead to pulmonary vascular remodeling and intraluminal obstruction. Thus, the blood leaving the right side of the heart encounters an increased resistance to flow. While this can occur at any stage of life, it is particularly important in neonatal and adult pulmonary medicine.

In the neonatal setting, $\mathrm{PH}$ is associated with several conditions including, congenital heart disease $\mathrm{e}^{94}$, connective tissue disease ${ }^{95}$ or sickle cell disease ${ }^{96}$, stenosis ${ }^{97,98}$, and chronic lung disease of prematurity 99,100 ; and in adults $\mathrm{PH}$ is commonly seen in 
chronic obstructive pulmonary disease (COPD) ${ }^{101-103}$, sleep disordered breathing (sleep apnea) $)^{104,105}$ and sickle cell disease $e^{106,107}$.

While hypoxia plays a pivotal role in the etiology, inducing pulmonary vessel constriction, and persistent hypoxia results in pulmonary vascular remodeling, leading further narrowing of the vessel, not all individuals subjected to hypoxia or hypoxemia develop pulmonary hypertension or other sequelae.

\section{INHIBITION OF MIF ACTIVITY}

The importance of MIF in the pathogenesis of disease has led to the development of inhibitory strategies to try to disrupt these processes. Early studies used polyclonal antibodies to inhibit MIF inflammatory activities to prevent the lethality in rodent models of acute hepatic failure ${ }^{108}$ and septic peritonitis ${ }^{109}$.

Since that time, Phase 1 clinical trials have assessed the possible use of anti-MIF antibodies cases of malignant solid tumors, metastatic adenocarcinoma ${ }^{110}$, and lupus nephritis ${ }^{111}$. However, a disadvantage of the monoclonal antibody approach as a therapeutic pathway, is the possible development of local and systemic inflammatory reactions during administration. Therefore, a second approach whereby endogenous anti-MIF antibodies are generated, has also been advanced. This method involves active immunization with an MIF/tetanus toxin DNA vaccine and has been shown to protect against acute lung injury resulting from endotoxemia or a septic peritonitis ${ }^{112}$.

In 2002, Leng et al demonstrated that MIF interacts with the extracellular domain of the HLA class II histocompatibility antigen gamma chain (CD74), initiating activation of cell proliferation, and prostaglandin E2 production ${ }^{34}$. Since that time there has been considerable effort expended on developing small molecule inhibitors that could block the MIF-CD74 interaction. Studies have suggested that an imino-quinone metabolite of acetaminophen, $\mathrm{N}$-acetyl-p-benzoquinone imine (NAPQI), can inhibit both the isomerase and inflammatory activities of MIF ${ }^{113}$.

Perhaps the most studied of these molecules is (S,R)-3-(4-hydroxyphenyl)-4,5-dihydro5 -isoxazole acetic acid methyl ester, or 'ISO-1'114,115. There have been many modifications on this and other chemical scaffolds to try to develop more effective and selective inhibitory molecules ${ }^{116-119}$. Recently, iguratimod, a novel antirheumatic drug ${ }^{120}$ used in China and Japan, was found to selectively inhibit MIF inflammatory activity ${ }^{121}$. In many cases these molecules have been found to modify the pathology of animal models.

\section{THYROXINE AS AN MIF INHIBITOR}

The thyroid hormone, thyroxine, 3,5, $3^{\prime}, 5^{\prime}$-tetraiodothyronine (T4), has been identified as a potent inhibitor of MIF proinflammatory activities ${ }^{122}$. T4 is produced in the thyroid at around $100 \mathrm{mg} / \mathrm{day}^{123}$. While previously considered solely as a prohormone and parent molecule for T3 (3,3',5-triiodo-L-thyronine), both molecules have been shown to elicit profound effects on myocardial activity ${ }^{124,125}$, and extra thyroidal conversion of T4 to $\mathrm{T}_{3}$, by specific deiodinases, occurs in a variety of tissues and precedes many thyroid hormone actions ${ }^{126}$.

Once released from the thyroid, thyroxine circulates in the blood, bound with thyroxine-binding globulin, transthyretin and albumin with only around $0.05 \%$ in the unbound, free-thyroxine ( $\left.\mathrm{fT}_{4}\right)$ form ${ }^{127}$. Cellular actions of thyroxine occur at the plasma membrane, in the cytoplasm in the mitochondria or the cell nucleus ${ }^{128}$.

Non-genomic action of T4, which can be initiated at approximate physiological concentrations of free $T_{4}$ of around $10^{-10} \mathrm{M}^{129}$, are initiated by interaction with the 
integrin av $\beta 3$ plasma membrane receptor, or in the cytoplasm ${ }^{130}$. Interaction with the integrin receptor on the cell surface stimulates MAPK (ERK1/2) activation ${ }^{125,129,130}$, leading to a series of downstream events including nuclear-trafficking of specific proteins and serine phosphorylation of nucleoproteins ${ }^{128}$, including estrogen receptor- $\alpha$, thyroid hormone nuclear receptor $\beta 1$, and signal transducing and activator of transcription (STAT) $-1 \alpha$.

While T4, and its hormonally inactive dextro-rotary isomer D-T4, are effective inhibitors of MIF activity, triiodothyronine (T3), a T4 metabolite, is not ${ }^{122}$. In a clinical situation such as sepsis, plasma concentrations of $\mathrm{T}_{4}$ and MIF are inversely correlated, suggesting a clinically-relevant interaction between these two molecules ${ }^{122}$. In addition, a potential role of MIF-T4 interactions in the pathogenesis of PAH has been suggested since $\mathrm{T}_{4}$ inhibits MIF-induced ERK $1 / 2$ phosphorylation in macrophages; T4 inhibits MIF activation of NF $\kappa B$ RelA/p65 in fibroblasts; and MIF inhibits T4-induced CXCR2 mRNA accumulation in vascular smooth muscle cells ${ }^{131}$. Thus, a schematic of potential mechanisms in vascular cells in hypoxia-induced altered MIF-T4 interactions is shown in Figure 2.

\section{INHIBITION OF MIF IN PULMONARY HYPERTENSION}

Studies from our group have found significantly increased plasma MIF concentrations in individuals with primary $\mathrm{PH}$ or $\mathrm{PH}$ secondary to interstitial lung disease, compared to control subjects ${ }^{45}$. Therefore, we examined the effect of MIF lung fibroblast growth and showed that the increased hypoxia-induced proliferation was MIF dependent. Furthermore, in a mouse model of hypoxia-induced pulmonary hypertension, the pulmonary vascular remodeling, increased right ventricular systolic pressures and right sided cardiac hypertrophy were all significantly decreased in the presence of a small molecule inhibitor of MIF. This suggests that MIF plays a significant role the development of $\mathrm{PH}$.

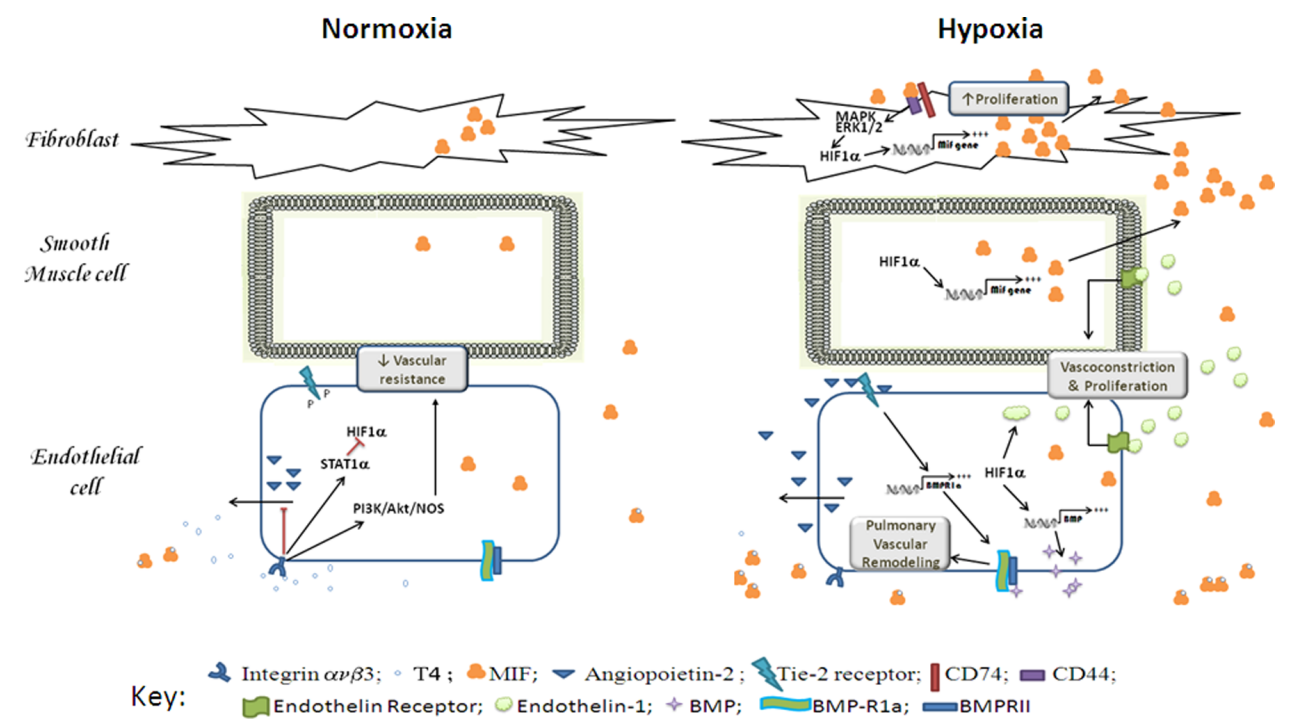

Figure 2. Potential mechanisms in vascular cells involving altered MIF-T4 interactions induced by hypoxia. Free thyroxine can bind to integrin avb3, decreasing extracellular ANG-2 accumulation and reducing vascular resistance. Hypoxia induces the stabilization of HIF1 $\alpha$ leading to the expression of endothelin-1 and MIF. Once released, Endothelin-1 and MIF induce cell proliferation. Hypoxia also induces production and release of BMP. Decreased $\mathrm{fT}_{4}$ (due to interaction with MIF) allows release of ANG-2 which binds its receptor TIE2 leading to transcription BMPR1a a component of the BMP receptor. Interaction between BMP and its receptor leads to altered vascular cell proliferation. 


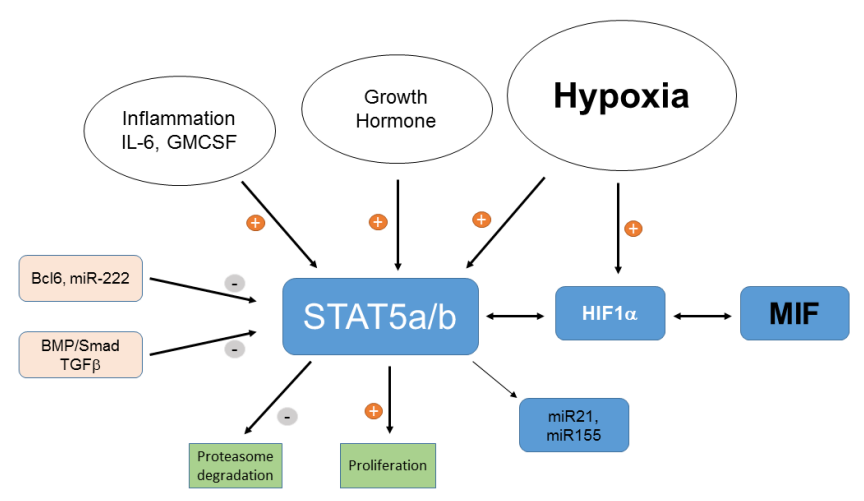

Figure 3. Relation between STAT5 and MIF in PH. Recent studies have highlighted the role of STAT5 in the pathogenesis of $\mathrm{PH}$, especially in the sex bias associated with the pathology ${ }^{135,136}$. STAT5 is the regulator of multiple genes. There is a functional interdependence between MIF and HIF1 $\alpha$, which can also impinge on STAT5 activity.

It should be noted, however, while in human idiopathic pulmonary arterial hypertension there is a two- to four-fold higher prevalence in postpubertal women than in men ${ }^{132}$, there is an opposite male-sex bias in the hypoxia, or monocrotaline rodent models of pulmonary hypertension 5,133,134.

In associated studies we examined the role of the signal transducer and activator of transcription 5 (STAT 5) in the development of PH, and showed decreased STAT5 expression in the obliterative lesions of human idiopathic PAH, and that deletion of STAT5 from the vascular smooth muscle cells abrogated the male bias ${ }^{135}$. This is of relevance since STAT 5 can act as a mediator in hypoxia-mediated gene expression ${ }^{136}$, and that, at least in some cells, MIF can promote intracellular signaling by STAT ${ }^{137}$ (Figure 3).

In addition to the pulmonary pathology, clinical studies suggest that PAH is also associated with cognitive impairment, depression and anxiety. Recent studies have shown, in the hypoxic mouse model, that hypoxia induces increased MIF accumulation within the hippocampus (at both level of mRNA and protein), and metabolic, biochemical, and electro-physiological changes within the hippocampus were associated with cognitive dysfunction. ${ }^{138,139}$. These hypoxia-driven changes were corrected by the administration of an MIF inhibitor ${ }^{138,140}$. However, it remains unclear whether the cognitive dysfunction was corrected by direct inhibition of the increased MIF within the hippocampus, or as a result of the improvement in pulmonary function.

\section{MIF INHIBITION IN CONGENITAL DIAPHRAGMATIC HERNIA (CDH)}

$\mathrm{CDH}$ is identified in around $1 / 3000$ newborns ${ }^{141}$. It results from a defective diaphragm allowing the protrusion of abdominal tissues into the thorax, thereby interfering with normal lung development leading to lung hypoplasia and persistent pulmonary hypertension of the newborn ${ }^{141}$. Rodent models of the condition have been developed, and often use administration of a single dose of 2,4-dichlorophenyl-P-nitrophenyl (Nitrofen) on the tenth gestational day ${ }^{142}$. Poor vascular growth in the $\mathrm{CDH}$ rat model is associated with poor lung growth. The exact mechanism of defective angiogenesis associated with $\mathrm{CDH}$ is not fully understood. However, studies show that inhibiting the MIF activity in the rat CDH model results in higher expression of VEGF and Tie-2 receptor while normalizing Sflt-1. Together, these molecular changes lead to a significant improvement in pulmonary angiogenesis as well as lung development as shown by CT and histological studies ${ }^{143}$. 


\section{MIF AND OTHER NEW PATHWAYS}

In addition to being a potent vascular vasodilator, nitric oxide (NO) enhances angiogenesis by activating endothelial cell growth and tube formation ${ }^{144}$. Neonatal rats with $\mathrm{CDH}$ were treated with ISO-92 and we observed a significant increase of phosphorylated eNOS (P-eNOS), which is known to increase NO production.

This was also associated with decreases in both arginase-1 and -2 expression. Arginase is a urea cycle enzyme which competes with endothelial NO synthetase (e NOS) and inhibits NO synthesis via a common substrate, L-arginine. Hypoxia upregulates the expression of both arginase enzymes ${ }^{145}$.

In our study, among neonates with $\mathrm{CDH}$, both arginase-1 and -2 enzymes were overexpressed significantly in comparison to healthy control neonates. This may suggest that, both NO production and its bioavailability were significantly compromised among neonates with $\mathrm{CDH}$.

We have shown that treating pregnant adult rats with ISO-92 after inducing $\mathrm{CDH}$ around day 8-9 of gestation, significantly decreased both arginase-1 and -2 expression, which is known to eventually increase NO production and its bioavailability. Accordingly, we postulate that inhibition of both arginase-1 and -2 , could be the mechanism through which inhibition of MIF activity (using ISO-92 in our model), can lead to increase NO bioavailability in utero, thereby improving pulmonary angiogenesis and lung development ${ }^{146}$.

\section{CONCLUSION AND FUTURE STUDIES}

Macrophage migration inhibitory factor is a key mediator of inflammatory responses and innate immunity and has been implicated in the pathogenesis of several inflammatory and autoimmune diseases. MIF's role in the pathogenesis of PAH, induced by chronic hypoxia, or associated with chronic lung diseases, or idiopathic, has been explored in many studies. The link between endothelial dysfunction and MIF in animals models with chronic PAH has been established. Other studies highlighted MIF role as a biomarker for the assessment of PAH associated with chronic obstructive lung diseases. Discovering the role played by 44 as a natural ligand inhibitor of MIF's inflammatory activity opens the door for new therapeutic role of anti-MIF's, as shown in preclinical and clinical data, which suggest that blocking the inflammatory active site of MIF may both reduce inflammatory responses and improve the availability of T4. Preclinical data using different anti-MIF's in different animal models with chronic and severe forms of pulmonary hypertension are very promising. Whether inhibition of MIF or its oxidized forms may offer promising therapy in $\mathrm{PAH}$, needs to be elaborated in future human interventional studies.

\section{ACKNOWLEDGEMENTS}

This review is supported in part by National Heart, Lung, and Blood Institute Grant HL111469 (EJM).

\section{REFERENCES}

[1] Rich S, Dantzker DR, Ayres SM, Bergofsky EH, Brundage BH, Detre KM, Fishman AP, Goldring RM, Groves BM, Koerner SK, et al. Primary pulmonary hypertension. A national prospective study. Ann Intern Med. 1987;107(2):216-23.

[2] Jing ZC, Xu XQ, Han ZY, Wu Y, Deng KW, Wang H, Wang ZW, Cheng XS, Xu B, Hu SS, Hui RT, Yang YJ. Registry and survival study in chinese patients with idiopathic and familial pulmonary arterial hypertension. Chest. 2007;132(2):373-9. 
[3] D’Alonzo GE, Barst RJ, Ayres SM, Bergofsky EH, Brundage BH, Detre KM, Fishman AP, Goldring RM, Groves BM, Kernis JT, et al. Survival in patients with primary pulmonary hypertension. Results from a national prospective registry. Ann Intern Med. 1991;115(5):343-9.

[4] Hyduk A, Croft JB, Ayala C, Zheng K, Zheng Z), Mensah GA. Pulmonary hypertension surveillance-United States, 1980-2002. MMWR Surveill Summ. 2005;54(5):1-28.

[5] Stenmark KR, Fagan KA, Frid MG. Hypoxia-induced pulmonary vascular remodeling: cellular and molecular mechanisms. Circ Res. 2006;99(7):675-91.

[6] Tuder RM, Yun JH, Bhunia A, Fijalkowska I. Hypoxia and chronic lung disease. J Mol Med (Berl). 2007;85(12):1317-24.

[7] Puri A, McGoon MD, Kushwaha SS. Pulmonary arterial hypertension: current therapeutic strategies. Nat Clin Pract Cardiovasc Med. 2007;4(6):319-29.

[8] Rosenkranz S. Pulmonary hypertension: current diagnosis and treatment. Clin Res Cardiol. 2007;96(8):527-41.

[9] Siobal MS. Pulmonary vasodilators. Respir Care. 2007;52(7):885-99.

[10] Macchia A, Marchioli R, Marfisi R, Scarano M, Levantesi G, Tavazzi L, Tognoni G. A meta-analysis of trials of pulmonary hypertension: a clinical condition looking for drugs and research methodology. Am Heart J. 2007;153(6):1037-47.

[11] Torres F. Systematic review of randomised, double-blind clinical trials of oral agents conducted in patients with pulmonary arterial hypertension. Int J Clin Pract. 2007;61(10):1756-65.

[12] Reid L, Meyrick B. Hypoxia and pulmonary vascular endothelium. Ciba Found Symp. 1980;78:37-60.

[13] Pak O, Aldashev A, Welsh D, Peacock A. The effects of hypoxia on the cells of the pulmonary vasculature. Eur Respir J. 2007;30(2):364-72.

[14] Preston IR, Hill NS, Warburton RR, Fanburg BL. Role of 12-lipoxygenase in hypoxia-induced rat pulmonary artery smooth muscle cell proliferation. Am J Physiol Lung Cell Mol Physiol. 2006;290(2):L367-74.

[15] Frank D, Johnson J, de Caestecker M. Bone morphogenetic protein 4 promotes vascular remodeling in hypoxic pulmonary hypertension. Chest. 2005;128(6 Suppl):590S-1S.

[16] Dempsey EC, McMurtry IF, O’Brien RF. Protein kinase C activation allows pulmonary artery smooth muscle cells to proliferate to hypoxia. Am J Physiol. 1991;260(2 Pt 1):L136-45.

[17] Lanner MC, Raper M, Pratt WM, Rhoades RA. Heterotrimeric G proteins and the platelet-derived growth factor receptor-beta contribute to hypoxic proliferation of smooth muscle cells. Am J Respir Cell Mol Biol. 2005;33(4):412-9.

[18] Stiebellehner L, Frid MG, Reeves JT, Low RB, Gnanasekharan M, Stenmark KR. Bovine distal pulmonary arterial media is composed of a uniform population of well-differentiated smooth muscle cells with low proliferative capabilities. Am J Physiol Lung Cell Mol Physiol. 2003;285(4):L819-28.

[19] Benitz WE, Coulson JD, Lessler DS, Bernfield M. Hypoxia inhibits proliferation of fetal pulmonary arterial smooth muscle cells in vitro. Pediatr Res. 1986;20(10):966-72.

[20] Rose F, Grimminger F, Appel J, Heller M, Pies V, Weissmann N, Fink L, Schmidt S, Krick S, Camenisch G, Gassmann M, Seeger W, Hanze J. Hypoxic pulmonary artery fibroblasts trigger proliferation of vascular smooth muscle cells: role of hypoxia-inducible transcription factors. Faseb J. 2002;16(12):1660-1.

[21] Das M, Burns N, Wilson SJ, Zawada WM, Stenmark KR. Hypoxia exposure induces the emergence of fibroblasts lacking replication repressor signals of PKCzeta in the pulmonary artery adventitia. Cardiovasc Res. 2008;78(3):440-8.

[22] Das M, Dempsey EC, Bouchey D, Reyland ME, Stenmark KR. Chronic hypoxia induces exaggerated growth responses in pulmonary artery adventitial fibroblasts: potential contribution of specific protein kinase c isozymes. Am J Respir Cell Mol Biol. 2000;22(1):15-25.

[23] Stenmark KR, Davie N, Frid M, Gerasimovskaya E, Das M. Role of the adventitia in pulmonary vascular remodeling. Physiology (Bethesda). 2006;21:134-45.

[24] Sartore S, Chiavegato A, Faggin E, Franch R, Puato M, Ausoni S, Pauletto P. Contribution of adventitial fibroblasts to neointima formation and vascular remodeling: from innocent bystander to active participant. Circ Res. 2001;89(12):1111-21.

[25] Belknap JK, Orton EC, Ensley B, Tucker A, Stenmark KR. Hypoxia increases bromodeoxyuridine labeling indices in bovine neonatal pulmonary arteries. Am J Respir Cell Mol Biol. 1997;16(4):366-71.

[26] Eul B, Rose F, Krick S, Savai R, Goyal P, Klepetko W, Grimminger F, Weissmann N, Seeger W, Hanze J. Impact of HIF-1alpha and HIF-2alpha on proliferation and migration of human pulmonary artery fibroblasts in hypoxia. Faseb J. 2006;20(1):163-5.

[27] Stenmark KR, Gerasimovskaya E, Nemenoff RA, Das M. Hypoxic activation of adventitial fibroblasts: role in vascular remodeling. Chest. 2002;122(6 Suppl):326S-34S.

[28] David JR. Delayed hypersensitivity in vitro: its mediation by cell-free substances formed by lymphoid cell-antigen interaction. Proc Natl Acad Sci U S A. 1966;56(1):72-7.

[29] Bloom BR, Bennett B. Mechanism of a reaction in vitro associated with delayed-type hypersensitivity. Science. 1966;153(3731):80-2.

[30] Calandra T, Bernhagen J, Metz CN, Spiegel LA, Bacher M, Donnelly T, Cerami A, Bucala R. MIF as a glucocorticoid-induced modulator of cytokine production. Nature. 1995;377(6544):68-71.

[31] Rosengren E, Aman P, Thelin S, Hansson C, Ahlfors S, Bjork P, Jacobsson L, Rorsman H. The macrophage migration inhibitory factor MIF is a phenylpyruvate tautomerase. FEBS Lett. 1997;417(1):85-8. 
[32] Odh G, Hindemith A, Rosengren AM, Rosengren E, Rorsman H. Isolation of a new tautomerase monitored by the conversion of D-dopachrome to 5,6-dihydroxyindole. Biochem Biophys Res Commun. 1993;197(2):619-24.

[33] Merk M, Zierow S, Leng L, Das R, Du X, Schulte W, Fan J, Lue H, Chen Y, Xiong H, Chagnon F, Bernhagen J, Lolis E, Mor G, Lesur O, Bucala R. The D-dopachrome tautomerase (DDT) gene product is a cytokine and functional homolog of macrophage migration inhibitory factor (MIF). Proc Natl Acad Sci U S A. 2011;108(34):E577-85.

[34] Leng L, Metz CN, Fang Y, Xu J, Donnelly S, Baugh J, Delohery T, Chen Y, Mitchell RA, Bucala R. MIF signal transduction initiated by binding to CD74. J Exp Med. 2003;197(11):1467-76.

[35] Shi X, Leng L, Wang T, Wang W, Du X, Li J, McDonald C, Chen Z, Murphy JW, Lolis E, Noble P, Knudson W, Bucala R. CD44 is the signaling component of the macrophage migration inhibitory factor-CD74 receptor complex. Immunity. 2006;25(4):595-606.

[36] Hudson JD, Shoaibi MA, Maestro R, Carnero A, Hannon GJ, Beach DH. A proinflammatory cytokine inhibits p53 tumor suppressor activity. J Exp Med. 1999;190(10):1375-82.

[37] Kleemann R, Kapurniotu A, Frank RW, Gessner A, Mischke R, Flieger O, Juttner S, Brunner H, Bernhagen J. Disulfide analysis reveals a role for macrophage migration inhibitory factor (MIF) as thiol-protein oxidoreductase. J Mol Biol. 1998;280(1):85-102.

[38] Koga K, Kenessey A, Powell SR, Sison CP, Miller EJ, Ojamaa K. Macrophage migration inhibitory factor provides cardioprotection during ischemia/reperfusion by reducing oxidative stress. Antioxid Redox Signal. 2011;14(7):1191-202.

[39] Miller EJ, Li J, Leng L, McDonald C, Atsumi T, Bucala R, Young LH. Macrophage migration inhibitory factor stimulates AMP-activated protein kinase in the ischaemic heart. Nature. 2008;451(7178):578-82.

[40] Merchant S, Nadaraj S, Chowdhury D, Parnell VA, Sison C, Miller EJ, Ojamaa K. Macrophage migration inhibitory factor in pediatric patients undergoing surgery for congenital heart repair. Mol Med. 2008;14(3-4):124-30.

[41] Bruchfeld A, Carrero JJ, Qureshi AR, Lindholm B, Barany P, Heimburger O, Hu M, Lin X, Stenvinkel P, Miller EJ. Elevated serum macrophage migration inhibitory factor (MIF) concentrations in chronic kidney disease (CKD) are associated with markers of oxidative stress and endothelial activation. Mol Med. 2009;15(3-4):70-5.

[42] Merk M, Baugh J, Zierow S, Leng L, Pal U, Lee SJ, Ebert AD, Mizue Y, Trent JO, Mitchell R, Nickel W, Kavathas PB, Bernhagen J, Bucala R. The Golgi-associated protein p115 mediates the secretion of macrophage migration inhibitory factor. J Immunol. 2009;182(11):6896-906.

[43] Calandra T. Macrophage migration inhibitory factor and host innate immune responses to microbes. Scand J Infect Dis. 2003;35(9):573-6.

[44] Froidevaux C, Roger T, Martin C, Glauser MP, Calandra T. Macrophage migration inhibitory factor and innate immune responses to bacterial infections. Crit Care Med. 2001;29(7 Suppl):S13-5.

[45] Zhang Y, Talwar A, Tsang D, Bruchfeld A, Sadoughi A, Hu M, Omonuwa K, Cheng KF, Al-Abed Y, Miller E). Macrophage migration inhibitory factor mediates hypoxia-induced pulmonary hypertension. Mol Med. 2012;18:215-23.

[46] Dewor M, Steffens G, Krohn R, Weber C, Baron J, Bernhagen J. Macrophage migration inhibitory factor (MIF) promotes fibroblast migration in scratch-wounded monolayers in vitro. FEBS Lett. 2007;581(24):4734-42.

[47] Lacey D, Sampey A, Mitchell R, Bucala R, Santos L, Leech M, Morand E. Control of fibroblast-like synoviocyte proliferation by macrophage migration inhibitory factor. Arthritis Rheum. 2003;48(1):103-9.

[48] Bucala R, Donnelly SC. Macrophage migration inhibitory factor: a probable link between inflammation and cancer. Immunity. 2007;26(3):281-5.

[49] Xia HH, Lam SK, Chan AO, Lin MC, Kung HF, Ogura K, Berg DE, Wong BC. Macrophage migration inhibitory factor stimulated by Helicobacter pylori increases proliferation of gastric epithelial cells. World J Gastroenterol. 2005;11(13):1946-50.

[50] Chattergoon NN, D'Souza FM, Deng W, Chen H, Hyman AL, Kadowitz PJ, Jeter Jr JR. Antiproliferative effects of calcitonin gene-related peptide in aortic and pulmonary artery smooth muscle cells. Am J Physiol Lung Cell Mol Physiol. 2005;288(1):L202-11.

[51] Hagemann T, Robinson SC, Thompson RG, Charles K, Kulbe H, Balkwill FR. Ovarian cancer cell-derived migration inhibitory factor enhances tumor growth, progression, and angiogenesis. Mol Cancer Ther. 2007;6(7):1993-2002.

[52] Meyer-Siegler KL, Leifheit EC, Vera PL. Inhibition of macrophage migration inhibitory factor decreases proliferation and cytokine expression in bladder cancer cells. BMC Cancer. 2004;4:34.

[53] Meyer-Siegler KL, Iczkowski KA, Leng L, Bucala R, Vera PL. Inhibition of macrophage migration inhibitory factor or its receptor (CD74) attenuates growth and invasion of DU-145 prostate cancer cells. J Immunol. 2006;177(12):8730-9.

[54] Petrenko O, Fingerle-Rowson G, Peng T, Mitchell RA, Metz CN. Macrophage migration inhibitory factor deficiency is associated with altered cell growth and reduced susceptibility to Ras-mediated transformation. J Biol Chem. 2003;278(13):11078-85.

[55] Mitchell RA, Metz CN, Peng T, Bucala R. Sustained mitogen-activated protein kinase (MAPK) and cytoplasmic phospholipase A2 activation by macrophage migration inhibitory factor (MIF). Regulatory role in cell proliferation and glucocorticoid action. J Biol Chem. 1999;274(25):18100-6.

[56] Petrenko O, Moll UM. Macrophage migration inhibitory factor MIF interferes with the Rb-E2F pathway. Mol Cell. 2005;17(2):225-36. 
[57] Swant JD, Rendon BE, Symons M, Mitchell RA. Rho GTPase-dependent signaling is required for macrophage migration inhibitory factor-mediated expression of cyclin D1. J Biol Chem. 2005;280(24):23066-72.

[58] Amin MA, Volpert OV, Woods JM, Kumar P, Harlow LA, Koch AE. Migration inhibitory factor mediates angiogenesis via mitogen-activated protein kinase and phosphatidylinositol kinase. Circ Res. 2003;93(4):321-9.

[59] Pan JH, Sukhova GK, Yang JT, Wang B, Xie T, Fu H, Zhang Y, Satoskar AR, David JR, Metz CN, Bucala R, Fang K, Simon DI, Chapman HA, Libby P, Shi GP. Macrophage migration inhibitory factor deficiency impairs atherosclerosis in low-density lipoprotein receptor-deficient mice. Circulation. 2004;109(25):3149-53.

[6o] Chen Z, Sakuma M, Zago AC, Zhang X, Shi C, Leng L, Mizue Y, Bucala R, Simon D. Evidence for a role of macrophage migration inhibitory factor in vascular disease. Arterioscler Thromb Vasc Biol. 2004;24(4):709-14.

[61] Korshunov VA, Nikonenko TA, Tkachuk VA, Brooks A, Berk BC. Interleukin-18 and macrophage migration inhibitory factor are associated with increased carotid intima-media thickening. Arterioscler Thromb Vasc Biol. 2006;26(2):295-300.

[62] Fingerle-Rowson G, Petrenko O, Metz CN, Forsthuber TG, Mitchell R, Huss R, Moll U, Muller W, Bucala R. The p53-dependent effects of macrophage migration inhibitory factor revealed by gene targeting. Proc Natl Acad Sci U S A. 2003;100(16):9354-9.

[63] Leech M, Lacey D, Xue JR, Santos L, Hutchinson P, Wolvetang E, David JR, Bucala R, Morand EF. Regulation of $\mathrm{p} 53$ by macrophage migration inhibitory factor in inflammatory arthritis. Arthritis Rheum. 2003;48(7):1881-9.

[64] Bernhagen J, Calandra T, Mitchell RA, Martin SB, Tracey KJ, Voelter W, Manogue KR, Cerami A, Bucala R. MIF is a pituitary-derived cytokine that potentiates lethal endotoxaemia. Nature. 1993;365(6448):756-9.

[65] Sakuragi T, Lin X, Metz CN, Ojamaa K, Kohn N, Al-Abed Y, Miller EJ. Lung-derived macrophage migration inhibitory factor in sepsis induces cardio-circulatory depression. Surgical Infection (LarChmt). 2007;18(1):29-41 Study was recognised with Surgical Infection Society New Member Award.

[66] Lin X, Sakuragi T, Metz CN, Ojamaa K, Skopicki HA, Wang P, Al-Abed Y, Miller EJ. Macrophage migration inhibitory factor within the alveolar spaces induces changes in the heart during late experimental sepsis. Shock. 2005;24(6):556-63.

[67] Donnelly SC, Haslett C, Reid PT, Grant IS, Wallace WA, Metz CN, Bruce LJ, Bucala R. Regulatory role for macrophage migration inhibitory factor in acute respiratory distress syndrome. Nat Med. 1997:3(3):320-3.

[68] Gao L, Flores C, Fan-Ma S, Miller EJ, Moitra J, Moreno L, Wadgaonkar R, Simon B, Brower R, Sevransky J, Tuder RM, Maloney JP, Moss M, Shanholtz C, Yates CR, Meduri GU, Ye SQ, Barnes KC, Garcia JG. Macrophage migration inhibitory factor in acute lung injury: expression, biomarker, and associations. Transl Res. 2007;150(1):18-29.

[69] Linge HM, Ochani K, Lin K, Lee JY, Miller EJ. Age-dependent alterations in the inflammatory response to pulmonary challenge. Immunol Res. 2015;63(1-3):209-15.

[70] Roger T, Schlapbach L), Schneider A, Weier M, Wellmann S, Marquis P, Vermijlen D, Sweep FC, Leng L, Bucala R, Calandra T, Giannoni E. Plasma levels of macrophage migration inhibitory factor and d-dopachrome tautomerase show a highly specific profile in early life. Front Immunol. 2017;8:26.

[71] Olivieri C, Bargagli E, Inghilleri S, Campo I, Cintorino M, Rottoli P. Macrophage migration inhibitory factor in lung tissue of idiopathic pulmonary fibrosis patients. Exp Lung Res. 2016;42(5):263-6.

[72] Bargagli E, Olivieri C, Nikiforakis N, Cintorino M, Magi B, Perari MG, Vagaggini C, Spina D, Prasse A, Rottoli P. Analysis of macrophage migration inhibitory factor (MIF) in patients with idiopathic pulmonary fibrosis. Respir Physiol Neurobiol. 2009;167(3):261-7.

[73] Selvi E, Tripodi SA, Catenaccio M, Lorenzini S, Chindamo D, Manganelli S, Romagnoli R, letta F, Paulesu L, Miracco C, Cintorino M, Marcolongo R. Expression of macrophage migration inhibitory factor in diffuse systemic sclerosis. Ann Rheum Dis. 2003;62(5):460-4.

[74] Bossini-Castillo L, Campillo-Davo D, Lopez-Isac E, Carmona FD, Simeon CP, Carreira P, Callejas-Rubio JL, Castellvi I, Fernandez-Nebro A, Rodriguez-Rodriguez L, Rubio-Rivas M, Garcia-Hernandez FJ, Madronero AB, Beretta L, Santaniello A, Lunardi C, Airo P, Hoffmann-Vold AM, Kreuter A, Riemekasten G, Witte T, Hunzelmann N, Vonk MC, Voskuyl AE, de Vries-Bouwstra J, Shiels P, Herrick A, Worthington J, Radstake T, Martin J. An MIF promoter polymorphism is associated with susceptibility to pulmonary arterial hypertension in diffuse cutaneous systemic sclerosis. J Rheumatol. 2017.

[75] Wu SP, Leng L, Feng Z, Liu N, Zhao H, McDonald C, Lee A, Arnett FC, Gregersen PK, Mayes MD, Bucala R. Macrophage migration inhibitory factor promoter polymorphisms and the clinical expression of scleroderma. Arthritis Rheum. 2006;54(11):3661-9.

[76] Husebo GR, Bakke PS, Gronseth R, Hardie JA, Ueland T, Aukrust P, Eagan TM. Macrophage migration inhibitory factor, a role in COPD. Am J Physiol Lung Cell Mol Physiol. 2016;311(1):L1-7.

[77] Sauler M, Leng L, Trentalange M, Haslip M, Shan P, Piecychna M, Zhang Y, Andrews N, Mannam P, Allore $H$, Fried T, Bucala R, Lee PJ. Macrophage migration inhibitory factor deficiency in chronic obstructive pulmonary disease. Am J Physiol Lung Cell Mol Physiol. 2014;306(6):L487-96.

[78] Fallica J, Boyer L, Kim B, Serebreni L, Varela L, Hamdan O, Wang L, Simms T, Damarla M, Kolb TM, Bucala R, Mitzner W, Hassoun PM, Damico R. Macrophage migration inhibitory factor is a novel determinant of cigarette smoke-induced lung damage. Am J Respir Cell Mol Biol. 2014;51(1):94-103. 
[79] Welford SM, Bedogni B, Gradin K, Poellinger L, Broome Powell M, Giaccia AJ. HIF1alpha delays premature senescence through the activation of MIF. Genes Dev. 2006;20(24):3366-71.

[80] Takahashi M, Nishihira J, Shimpo M, Mizue Y, Ueno S, Mano H, Kobayashi E, Ikeda U, Shimada K. Macrophage migration inhibitory factor as a redox-sensitive cytokine in cardiac myocytes. Cardiovasc Res. 2001;52(3):438-45.

[81] Schmeisser A, Marquetant R, Illmer T, Graffy C, Garlichs CD, Bockler D, Menschikowski D, Braun-Dullaeus R, Daniel WG, Strasser RH. The expression of macrophage migration inhibitory factor 1alpha (MIF 1alpha) in human atherosclerotic plaques is induced by different proatherogenic stimuli and associated with plaque instability. Atherosclerosis. 2005;178(1):83-94.

[82] Maity A, Koumenis C. HIF and MIF-a nifty way to delay senescence? Genes Dev. 2006;20(24):3337-41.

[83] Baugh JA, Gantier M, Li L, Byrne A, Buckley A, Donnelly SC. Dual regulation of macrophage migration inhibitory factor (MIF) expression in hypoxia by CREB and HIF-1. Biochem Biophys Res Commun. 2006;347(4):895-903.

[84] letta F, Wu Y, Romagnoli R, Soleymanlou N, Orsini B, Zamudio S, Paulesu L, Caniggia I. Oxygen regulation of macrophage migration inhibitory factor in human placenta. Am J Physiol Endocrinol Metab. 2007;292(1):E272-80.

[85] Winner M, Koong AC, Rendon BE, Zundel W, Mitchell RA. Amplification of tumor hypoxic responses by macrophage migration inhibitory factor-dependent hypoxia-inducible factor stabilization. Cancer Res. 2007;67(1):186-93.

[86] Winner M, Leng L, Zundel W, Mitchell RA. Macrophage migration inhibitory factor manipulation and evaluation in tumoral hypoxic adaptation. Methods Enzymol. 2007:435:355-69.

[87] Rahat MA, Marom B, Bitterman H, Weiss-Cerem L, Kinarty A, Lahat N. Hypoxia reduces the output of matrix metalloproteinase-9 (MMP-9) in monocytes by inhibiting its secretion and elevating membranal association. J Leukoc Biol. 2006;79(4):706-18.

[88] Zhang B, Luo Y, Liu ML, Wang J, Xu DQ, Dong MQ, Liu Y, Xu M, Dong HY, Zhao PT, Gao YQ, Li ZC. Macrophage migration inhibitory factor contributes to hypoxic pulmonary vasoconstriction in rats. Microvasc Res. 2012;83(2):205-12.

[89] Krick S, Hanze J, Eul B, Savai R, Seay U, Grimminger F, Lohmeyer J, Klepetko W, Seeger W, Rose F. Hypoxia-driven proliferation of human pulmonary artery fibroblasts: cross-talk between HIF-1alpha and an autocrine angiotensin system. Faseb J. 2005;19(7):857-9.

[90] Short M, Nemenoff RA, Zawada WM, Stenmark KR, Das M. Hypoxia induces differentiation of pulmonary artery adventitial fibroblasts into myofibroblasts. Am J Physiol Cell Physiol. 2004;286(2):C416-25.

[91] Clancy RM, Zheng P, O’Mahony M, Izmirly P, Zavadil J, Gardner L, Buyon JP. Role of hypoxia and cAMP in the transdifferentiation of human fetal cardiac fibroblasts: implications for progression to scarring in autoimmune-associated congenital heart block. Arthritis Rheum. 2007:56(12):4120-31.

[92] Sakuragi T, Lin X, Metz CN, Ojamaa K, Kohn N, Al-Abed Y, Miller EJ. Lung-derived macrophage migration inhibitory factor in sepsis induces cardio-circulatory depression. Surg Infect (LarChmt). 2007;8(1):29-40.

[93] Talwar A, Omonuwa K, Zhang Y, Tsang D, Dedopoulos S, Miller EJ. Macrophage miration inhiitory factor (MIF) is released from the lungs in patients with pulmonary hypertension (PH). Am J Respir Cell Mol Biol. 2009;179:A4887.

[94] Abman SH. Pulmonary hypertension in children: a historical overview. Pediatr Crit Care Med. 2010;11(2 Suppl):S4-9.

[95] Ivy DD, Abman SH, Barst RJ, Berger RM, Bonnet D, Fleming TR, Haworth SG, Raj JU, Rosenzweig EB, Schulze Neick I, Steinhorn RH, Beghetti M. Pediatric pulmonary hypertension. J Am Coll Cardiol. 2013;62(25 Suppl):D117-26.

[96] Powars DR, Chan LS, Hiti A, Ramicone E, Johnson C. Outcome of sickle cell anemia: a 4-decade observational study of 1056 patients. Medicine (Baltimore). 2005;84(6):363-76.

[97] Hilgendorff A, Apitz C, Bonnet D, Hansmann G. Pulmonary hypertension associated with acute or chronic lung diseases in the preterm and term neonate and infant. The European Paediatric Pulmonary Vascular Disease Network, endorsed by ISHLT and DGPK. Heart. 2016;102(Suppl 2):ii49-56.

[98] Lopes LM, Carrilho MC, Francisco RP, Lopes MA, Krebs VL, Zugaib M. Fetal ductus arteriosus constriction and closure: analysis of the causes and perinatal outcome related to 45 consecutive cases. I Matern Fetal Neonatal Med. 2016;29(4):638-45.

[99] Krishnan U, Rosenzweig EB. Pulmonary hypertension in chronic lung disease of infancy. Curr Opin Pediatr. 2015;27(2):177-83.

[100] Joshi S, Wilson DG, Kotecha S, Pickerd N, Fraser AG. Cardiovascular function in children who had chronic lung disease of prematurity. Arch Dis Child Fetal Neonatal Ed. 2014;99(5):F373-9.

[101] Westney G, Foreman MG, Xu J, King MHenriques, Flenaugh E, Rust G. Impact of comorbidities among medicaid enrollees with chronic obstructive pulmonary disease, United States, 2009. Prev Chronic Dis. 2017;14:E31.

[102] Plesner LL, Schoos MM, Dalsgaard M, Goetze JP, Kjoller E, Vestbo J, Iversen K. Iron deficiency in COPD associates with increased pulmonary artery pressure estimated by echocardiography. Heart Lung Circ. 2017;26(1):101-4.

[103] Calcaianu G, Canuet M, Schuller A, Enache I, Chaouat A, Kessler R. Pulmonary arterial hypertensionspecific drug therapy in COPD patients with severe pulmonary hypertension and mild-to-moderate airflow limitation. Respiration. 2016;91(1):9-17.

[104] Minic M, Granton JT, Ryan CM. Sleep disordered breathing in group 1 pulmonary arterial hypertension. J Clin Sleep Med. 2014;10(3):277-83. 
[105] Prisco DL, Sica AL, Talwar A, Narasimhan M, Omonuwa K, Hakimisefat B, Dedopoulos S, Shakir N, Greenberg H. Correlation of pulmonary hypertension severity with metrics of comorbid sleep-disordered breathing. Sleep Breath. 2011;15(4):633-9.

[106] Musa BM, Galadanci NA, Coker M, Bussell S, Aliyu MH. The global burden of pulmonary hypertension in sickle cell disease: a systematic review and meta-analysis. Ann Hematol. 2016;95(11):1757-64.

[107] Gordeuk VR, Castro OL, Machado RF. Pathophysiology and treatment of pulmonary hypertension in sickle cell disease. Blood. 2016;127(7):820-8.

[108] Kobayashi S, Nishihira J, Watanabe S, Todo S. Prevention of lethal acute hepatic failure by antimacrophage migration inhibitory factor antibody in mice treated with bacille Calmette-Guerin and lipopolysaccharide. Hepatology. 1999;29(6):1752-9.

[109] Calandra T, Echtenacher B, Roy DL, Pugin J, Metz CN, Hultner L, Heumann D, Mannel D, Bucala R, Glauser MP. Protection from septic shock by neutralization of macrophage migration inhibitory factor. Nat Med. 2000;6(2):164-70.

[110] Baxalta Ul. 2013. Study of Anti-Macrophage Migration Inhibitory Factor (Anti-MIF) antibody in solid tumors. ClinicalTrialsgov Identifier: NCT01765790.

[111] Baxalta UI. 2012. Safety study of Anti-Macrophage Migration Inhibitory Factor (Anti-MIF) antibody in Lupus Nephritis. ClinicalTrialsgov Identifier: NCT01541670.

[112] Tohyama S, Onodera S, Tohyama H, Yasuda K, Nishihira J, Mizue Y, Hamasaka A, Abe R, Koyama Y. A novel DNA vaccine-targeting macrophage migration inhibitory factor improves the survival of mice with sepsis. Gene Ther. 2008;15(23):1513-22.

[113] Senter PD, Al-Abed Y, Metz CN, Benigni F, Mitchell RA, Chesney J, Han J, Gartner CG, Nelson SD, Todaro G), Bucala R. Inhibition of macrophage migration inhibitory factor (MIF) tautomerase and biological activities by acetaminophen metabolites. Proc Natl Acad Sci U S A. 2002;99(1):144-9.

[114] Lubetsky JB, Dios A, Han J, Aljabari B, Ruzsicska B, Mitchell R, Lolis E, Al-Abed Y. The tautomerase active site of macrophage migration inhibitory factor is a potential target for discovery of novel antiinflammatory agents. J Biol Chem. 2002;277(28):24976-82.

[115] Al-Abed Y, Dabideen D, Aljabari B, Valster A, Messmer D, Ochani M, Tanovic M, Ochani K, Bacher M, Nicoletti F, Metz C, Pavlov VA, Miller EJ, Tracey KJ. ISO-1 binding to the tautomerase active site of MIF inhibits its pro-inflammatory activity and increases survival in severe sepsis. J Biol Chem. 2005;280(44):36541-4.

[116] Cheng KF, Al-Abed Y. Critical modifications of the ISO-1 scaffold improve its potent inhibition of macrophage migration inhibitory factor (MIF) tautomerase activity. Bioorg Med Chem Lett. 2006;16(13):3376-9.

[117] Ioannou K, Cheng KF, Crichlow GV, Birmpilis Al, Lolis EJ, Tsitsilonis OE, Al-Abed Y. ISO-66, a novel inhibitor of macrophage migration, shows efficacy in melanoma and colon cancer models. Int J Oncol. 2014;45(4):1457-68.

[118] Dabideen DR, Cheng KF, Aljabari B, Miller EJ, Pavlov VA, Al-Abed Y. Phenolic hydrazones are potent inhibitors of macrophage migration inhibitory factor proinflammatory activity and survival improving agents in sepsis. J Med Chem. 2007;50(8):1993-7.

[119] Crichlow GV, Cheng KF, Dabideen D, Ochani M, Aljabari B, Pavlov VA, Miller E), Lolis E, Al-Abed Y. Alternative chemical modifications reverse the binding orientation of a pharmacophore scaffold in the active site of macrophage migration inhibitory factor. J Biol Chem. 2007;282(32):23089-95.

[120] Luo Q, Sun Y, Liu W, Qian C, Jin B, Tao F, Gu Y, Wu X, Shen Y, Xu Q. A novel disease-modifying antirheumatic drug, iguratimod, ameliorates murine arthritis by blocking IL-17 signaling, distinct from methotrexate and leflunomide. J Immunol. 2013;191(10):4969-78.

[121] Bloom J, Metz C, Nalawade S, Casabar J, Cheng KF, He M, Sherry B, Coleman T, Forsthuber T, Al-Abed Y. Identification of iguratimod as an inhibitor of macrophage migration inhibitory factor (MIF) with steroidsparing potential. J Biol Chem. 2016;291(51):26502-14.

[122] Al-Abed Y, Metz CN, Cheng KF, Aljabari B, VanPatten S, Blau S, Lee H, Ochani M, Pavlov VA, Coleman T, Meurice N, Tracey KJ, Miller EJ. Thyroxine is a potential endogenous antagonist of macrophage migration inhibitory factor (MIF) activity. P Natl Acad Sci USA. 2011;108(20):8224-7.

[123] Bunevicius R, Kazanavicius G, Zalinkevicius R, Prange Jr AJ. Effects of thyroxine as compared with thyroxine plus triiodothyronine in patients with hypothyroidism. N Engl J Med. 1999;340(6):424-9.

[124] Shih A, Lin HY, Davis FB, Davis PJ. Thyroid hormone promotes serine phosphorylation of p53 by mitogen-activated protein kinase. Biochemistry. 2001;40(9):2870-8.

[125] Davis PJ, Leonard JL, Davis FB. Mechanisms of nongenomic actions of thyroid hormone. Front Neuroendocrinol. 2008;29(2):211-8.

[126] Gereben B, Zeold A, Dentice M, Salvatore D, Bianco AC. Activation and inactivation of thyroid hormone by deiodinases: local action with general consequences. Cell Mol Life Sci. 2008;65(4):570-90.

[127] Pappa TA, Vagenakis AG, Alevizaki M. The nonthyroidal illness syndrome in the non-critically ill patient. Eur J Clin Invest. 2011;41(2):212-20.

[128] Cheng SY, Leonard JL, Davis PJ. Molecular aspects of thyroid hormone actions. Endocr Rev. 2010;31(2):139-70.

[129] Davis PJ, Shih A, Lin HY, Martino LJ, Davis FB. Thyroxine promotes association of mitogen-activated protein kinase and nuclear thyroid hormone receptor (TR) and causes serine phosphorylation of TR. J Biol Chem. 2000;275(48):38032-9. 
[130] Scarlett A, Parsons MP, Hanson PL, Sidhu KK, Milligan TP, Burrin JM. Thyroid hormone stimulation of extracellular signal-regulated kinase and cell proliferation in human osteoblast-like cells is initiated at integrin alphaVbeta3. J Endocrinol. 2008;196(3):509-17.

[131] Lee J, Stefaniak J, Lin K, Talwar A, Al-Abed Y, EJM. Potential role For macrophage migration inhibitory factor (MIF)-thyroxine (T4) interactions in the pathogenesis of pulmonary arterial hypertension (PAH). Am J Respir Crit Care Med. 2013;187:A1773.

[132] Austin ED, Lahm T, West J, Tofovic SP, Johansen AK, Maclean MR, Alzoubi A, Oka M. Gender, sex hormones and pulmonary hypertension. Pulm Circ. 2013;3(2):294-314.

[133] Dempsie Y, MacLean MR. The influence of gender on the development of pulmonary arterial hypertension. Exp Physiol. 2013;98(8):1257-61.

[134] Lahm T, Tuder RM, Petrache I. Progress in solving the sex hormone paradox in pulmonary hypertension. Am J Physiol Lung Cell Mol Physiol. 2014;307(1):L7-26.

[135] Yang YM, Yuan H, Edwards JG, Skayian Y, Ochani K, Miller EJ, Sehgal PB. Deletion of STAT5a/b in vascular smooth muscle abrogates the male bias in hypoxic pulmonary hypertension in mice: implications in the human disease. Mol Med. 2014;20:625-38.

[136] Joung YH, Park JH, Park T, Lee CS, Kim OH, Ye SK, Yang UM, Lee KJ, Yang YM. Hypoxia activates signal transducers and activators of transcription 5 (STAT5) and increases its binding activity to the GAS element in mammary epithelial cells. Exp Mol Med. 2003;35(5):350-7.

[137] Polajeva J, Bergstrom T, Edqvist PH, Lundequist A, Sjosten A, Nilsson G, Smits A, Bergqvist M, Ponten F, Westermark B, Pejler G, Forsberg Nilsson K, Tchougounova E. Glioma-derived macrophage migration inhibitory factor (MIF) promotes mast cell recruitment in a STAT5-dependent manner. Mol Oncol. 2014;8(1):50-8.

[138] Frattini S, Cheng KF, Ahmed M, Dewey SL, Talwar A, Ochani K, Lin K, Huerta PT, Y A-A, Miller EJ. 2015. Prevention of hypoxia-induced vascular remodeling and cognitive dysfunction. In: Presented at: Keystone symposia hypoxia: From basic mechanisms to therapeutics. Royal Dublin Society May 2015 Dublin.

[139] Zaghloul N, Patel H, Codipilly C, Marambaud P, Dewey S, Frattini S, Huerta PT, Nasim M, Miller EJ, Ahmed M. Overexpression of extracellular superoxide dismutase protects against brain injury induced by chronic hypoxia. PLoS One. 2014;9(9):e108168.

[140] Miller EJ, Al-Abed Y, Zhang Y, Cheng KF inventors, The Feinstein Institute for Medical Research, Manhasset NY, assignee. 2016. A method for treating a neurological disorder associated with hypoxia, using a small molecule MIF inhibitor. United States patent US 9,457,013.

[141] Chandrasekharan PK, Rawat M, Madappa R, Rothstein DH, Lakshminrusimha S. Congenital diaphragmatic hernia - a review. Matern Health Neonatol Perinatol. 2017;3:6.

[142] Tenbrinck R, Tibboel D, Gaillard JL, Kluth D, Bos AP, Lachmann B, Molenaar JC. Experimentally induced congenital diaphragmatic hernia in rats. J Pediatr Surg. 1990;25(4):426-9.

[143] Perveen S, Patel H, Ochani K, Orner D, Al-Abed Y, Miller E, Ahmed M. 2014. Role of antenatal use of MIF inhibition in preventing lung hypoplasia and PPHN among neonates with congenital diaphragmatic hernia. PAS meeting Abstract \#2313445.

[144] Acker SN, Seedorf GJ, Abman SH, Nozik-Grayck E, Partrick DA, Gien J. Pulmonary artery endothelial cell dysfunction and decreased populations of highly proliferative endothelial cells in experimental congenital diaphragmatic hernia. Am J Physiol Lung Cell Mol Physiol. 2013;305(12):L943-52.

[145] Wang L, Bhatta A, Toque HA, Rojas M, Yao L, Xu ZM, Patel C, Caldwell RB, Caldwell RW. Arginase inhibition enhances angiogenesis in endothelial cells exposed to hypoxia. Microvascular Research. 2015;98:1-8.

[146] Perveen S, Ayyasola K, Patel H, Ochani K, Benveniste H, Zuo Z, Salerno M, Vaska P, Miller E, Ahmed M. 2017. MIF inhibition enhances pulmonary angiogenesis and lung development in congenital diaphragmatic hernia. PAS meeting, \#: 2699971. 